\title{
Method of Parents in the Development of Child Prayers Attention Deficit Hyperactivity Disorder (ADHD) \\ (Case Study of ADHD Children in Kulam Kemukiman Syamtarail Village, North Aceh)
}

\author{
Muhajir ${ }^{1}, Z_{\text {Zahrul Mubarrak }}{ }^{1}$, Amiruddin $^{1}$, Khaidir $^{1}$, Fazil Saputra $^{2}$, Muhammad Ridha $^{2}$ \\ ${ }^{1}$ Lecturer of Institut Agama Islam (IAI) Al-Aziziyah Samalanga Bireuen Aceh \\ ${ }^{2}$ Magister Student of Institut Agama Islam (IAI) Al-Aziziyah Samalanga Bireuen Aceh \\ Email: ajir_daudi@yahoo.co.id
}

\begin{abstract}
Concentration disorders accompanied by hyperactivity in children with ADHD are conditions that show symptoms of lack concentration, hyperactivity and impulsiveness that causes an imbalance of most of their life activities. This makes parents have difficulty in providing prayer guidance to children who have ADHD. Starting from this problem, the researcher tries to make a scientific about Parents' Method in the Development of Child Prayers Attention Deficit Hyperactivity Disorder (ADHD) (Case Study of ADHD Children in Kulam Kemukiman Syamtarail Village, North Aceh)." This study was conducted to describe the method parents in providing prayer services to children with ADHD in Kulam Kemukiman Syamtarail Village, North Aceh. This thesis research method uses the case study method which is a study that tries to examine individuals or a unit in depth with a qualitative approach. In collecting data researchers conducted observations and direct interviews within formants who have been used as samples, as well as documentation. While the analysis of data through observations in this thesis uses a theme analysis model technique where all data after being collected will be processed one by one. The results showed that $A D H D$ children's prayer guidance involved all family members, namely the father, mother, siblings and cousins of ADHD children. As for the methods carried out by the family in the guidance of prayers in children with ADHD can be concluded as follows:1. Intelegently; 2. Be haviour; 3. By monitoring.
\end{abstract}

Keyword: Method in guiding the children's Attention Deficit Hyperactivity Disorde (ADHD)

\section{Introduction}

Allah SWT created people only to worship Him so that they would know and worship Him. As Allah SWTT said which means: "And I did not create jin and men but to worship Me" (Adz-Dzariyat: 56) 2. Therefore, Islam makes servitude (ta'abud or worship) to Allah the first obligation required of a Muslim. The pillars of Islam which consist of two sentences of Shahada, establishing prayer, issuing testes, fasting Ramadan and making the pilgrimage to Baitullah are the embodiments of Ta'abud to Allah SWT' ${ }^{3}$

To achieve the quality of worship that is perfect in adulthood, it is advisable to conduct religious worship from an early age, from childhood. Because in this phase the children are more at home so the parents are very active in carrying out their duties and obligations in carrying out religious guidance for their children. Things to remember as said Muh. Suwaid, that childhood is not a time of loading or giving obligations. He is a period of preparation, training and habituation to welcome the period of

\footnotetext{
2 Depag RI Mushaf Al-Qur'an Terjemahan Edisi Tabun 2000 (Jakarta Al Huda Kelompok Gema Insani, 2005), p. 524.

${ }^{3}$ Yusuf Qardhawi, Fiqih Puasa (Solo : Era Intermedia, 2006), p.17.
} 
imposition of obligations (taklif) when he later. That way, in the future implementation of obligations will feel easy and light, while also already having a mature readiness to explore life with confidence. ${ }^{4}$ This is in line with the opinion of Sheikh Jamaludin Mahfudz that from an early age a child must be trained in worship, ordered to do it and taught things that are forbidden and halal. Islam emphasizes Muslims to order their children to pray when they are 7 years old. Likewise, getting children in the habit of fasting is so that they are patient in their worship and in dealing with the burdens of life. ${ }^{5}$ Prayers are the first worship required by Allah.prayer has a great position in Islam and has its own position in Islam that is unmatched by any other position of worship.

Prayers are the most important testament that parents must give to their children. As Lukman's testament to his son in the word of God which means it is stated as follows "O my son, establish prayer and ask (humans) to do what is wrong and prevent (them) from actions that are unjust and be patient with what befalls you. Verily, such is an important matter. "(Luqman: 17) ${ }^{6}$

In children aged 10-13 years generally the skills to do the prayer are good. They have mastered the movements of Sholat (prayer), Words of Prayer, the things that cancel prayer. This is because from an early age they have been introduced to the prayer of prayer through direct example from parents or guidance through various media. In addition, in terms of children's intellectual mental development, they can already react to intellectual stimulation or carry out learning tasks that demand intellectual abilities or cognitive abilities (reading, writing and counting) ${ }^{7}$. And in terms of their psychomotor development, their motor movements can be well coordinated. Of course this development is different in children who experience attention deficit disorders accompanied by hyperactivity.

Concentration disorders accompanied by hyperactivity or in foreign terms is called ADHD (Attention Deficit Hyperactivity Disorder), which is a behavior disorder that has 3 main symptoms, namely inattention, hyperactivity and impulsivity. Inattention or lack of concentration can be seen from the failure of a child to give full attention to something. Symptoms of hyperactivity can be seen from the behavior of children who can not be silent. Impulsive symptoms are characterized by the difficulty of the child to delay the response. ${ }^{8}$ From the characteristics and abilities of ADHD above, of course ADHD children have difficulty in mastering prayer. Because prayer is a worship that requires high concentration and calmness. From the above problem, the researcher is interested in examining the family in Kulam Village, Syamtarail settlement, Syamtalira Aron district, North Aceh. The family has children with impaired concentration accompanied by hyperactivity, making it difficult for their parents to provide prayer guidance for their children with ADHD.

Regarding this, parents of ADHD children have guided prayer since ADHD children were still small. This guidance is carried out at home, ${ }^{10}$ because after all ADHD children are more at home than at school. This guidance also involves all family members at home. Because this guidance will be effective and optimal if there is good cooperation between family members. In this study, the study will focus on researching the methods used by parents of children with ADHD in teaching prayer to their children who are experiencing impaired concentration and hyperactivity.

\footnotetext{
${ }^{4}$ Muh.Suwaid, Mendidik. Anak Bersama Nabi S AW, terj. Salafuddin Abu Sayyid (Solo: Pustaka Arafah, 2006), p. 174. ${ }^{5}$ Syekh Jamaludin Mahfudz, Psikologi Anak dan Remaja Muslim (Jakarta: Pustakaal-Kautsar,2003), p.126.

${ }^{6}$ Depag RI, Mushafal-Qur'an Terjemah Edisi Tahun 2005 (Jakarta:Al-Huda Kelompok Gema Insani, 2005), p. 413.

${ }^{7}$ Elfi Yuliana Rohmah, Psiklogi Perkembangan (Ponorogo: STAIN Ponorogo Press, 2005), p. 166.

${ }^{8}$ D.s Prasetyono, Serba-Serbi Anak Autis (Jogjakart: Diva Press, 2008), p.107.

${ }^{9} \mathrm{Mr}$ Ibrahim's Interview (one of society in Ampeh Village, Syamtalira Aron District, North Aceh) at Thursday, 18th July 2019, at 10.00 a.m in his home)

${ }^{10}$ The Result's Interview of Parent 's Child's ADHD at Monday, 22nd July 2019, at 10.30 in his house.
} 


\section{Review of Literature}

\subsection{Coaching Method function}

Etymologically the term method comes from the Greek "metodos", this word consists of two syllables, namely "metha" which means through or passing and "hodos" which means way or way. Method means a path traveled to reach the goal. ${ }^{11}$ According to Winarno Surachmad the method is a way in which its function is a tool to achieve the goal. ${ }^{12}$ The method implies that the use of the process is consistent, and systematic, because remembering that the target method is a person who is experiencing growth and development. So the use of the method in the process of coaching or education is essentially the implementation of prudential attitudes in the work of fostering or educating so that science channeled easily absorbed.

So that it can be understood that the method means a way that must be traversed to present several lessons in order to achieve the teaching objectives. The method by which the author intends here is a way that parents do in teaching prayer to children so that the initial purpose of education can be realized as expected.

According to the Indonesian Indonesian dictionary, coaching is an effort, action and activity carried out efficiently and effectively to obtain better results. According to Yuridik Yahya the definition or understanding of coaching is a guidance or direction carried out consciously by adults to children who are not yet mature in order to be mature, independent and have a whole and mature personality. ${ }^{13}$ The term coaching or means "education" is help given deliberately by adults to children who are not yet mature to become a more independent person.

So, it can be understood that coaching is a process carried out to change the behavior of individuals and shape their personalities so that what they aspire can be achieved in accordance with what is expected. The coaching that the author intends in this discussion is an attempt to educate the child's personality so that he is independent and perfect and can be responsible for what has been charged to him.

Guidance in Education is more directed towards the formation and formation of human attitudes and personalities whose scope includes the process of influencing and shaping cognitive, affective and psychomotor abilities in humans. It is different from teaching which focuses more on the efforts to form a maximum intellectual ability to receive, understand, appreciate and master and develop the knowledge being taught. ${ }^{14}$ In this regard, the strategy used is to understand the psychological condition of children, their behavior patterns, character, life patterns and patterns of understanding of religion. Among some of the educational methods that have been described above, then subsequently there are several methods or methods used in the implementation of fostering prayer for children, namely: Habit, exemplary, practice, attention with advice, punishment or reward and training methods. ${ }^{15}$

\subsection{ADHD Children (Attention Deficit Hyperactivity Disorder)}

ADHD is a popular abbreviation for attention deficit hyperactivity disorder. In Indonesian, ADHD means attention deficit disorder accompanied by hyperactivity. ${ }^{16}$ This disorder is also called hyperkinetic disorder and minimal brain dysfunction syndrome. ${ }^{17}$

\footnotetext{
${ }^{11}$ M. Arifin, Ilmu Pendidikdn Islam, Cet. V, (Jakarta: Bumi Aksara, 1996), p. 61

12 Winarno surachmad, Metodelogi Pengajaran, (Bandung: Jemmar, 1998), p. 75

13 Yuridi Yahya, Ilmu Pendidikan Islam (Jakarta: Bumi Aksara, 1995), p. 65

${ }^{14}$ H. M. Arifin, Filsafat Pendidikan Islam, (Jakarta: Bumi Aksara, 1993), p. 100.

${ }^{15}$ Syaiful Bahri Djamarah, dkk, Strategi Belajar Mengajar,(Jakarta: Rineka Cipta, 2002), p.72

16 M.I.F Baihaqi dan M.Sugiarmin. Memahami dan Membantu Anak. ADHD(Bandung:PT. Refika Aditama, 2006$)$ p. 2.
} 
The term ADHD may be a new term, but children who exhibit overactive and uncontrolled behavior have been around for a long time. In 1845 Heinrich Hoffman, a neurologist, for the first time wrote about the behavior that came to be known as hyperactivity in his book 'children's stories'. ADHD was first discovered in 1902 by an Englishman, Prof. George F. Still in his study of a group of children who showed an inability to focus attention, anxiety and anxiety.

Previously there was the term ADD, short for attention deficit disorder which means 'attention deficit disorder'. When you add hyperactivity / hyperactivity, the terms are varied. Some wrote ADHD, $\mathrm{AD}-\mathrm{HD}$ and some wrote ADD / H. But actually from the three types of writing terms, the meaning is the same. ${ }^{18}$

To be called having an ADHD disorder there must be 3 main symptoms that appear in a child's behavior, namely inattention, hyperactivity and impulsivity. Inattention or lack of concentration can be seen from the failure of a child to give full attention to something. Symptoms of hyperactivity can be seen from the behavior of children who can not be silent. Impulsive symptoms are characterized by the child's difficulty in responding. ${ }^{19}$

According to Ferdinand Zaviera, children with ADHD have the following characteristics: ${ }^{20}$ a. Not focus

Children with hyperactivity disorders cannot concentrate for more than 5 minutes. In other words, he could not stay still for a long time and his attention was easily diverted to other things. b. Against

Children with hyperactivity disorders generally have an attitude of resistance or rebellion or do not want to be advised, for example, sufferers will get angry if it is prohibited to go here and there, scribble and so on.

c. Destructive

His behavior is destructive or destructive. When arranging legos for example, active children will finish it neatly. However, hyperactive children actually destroy lego toys that are neatly arranged.

d. Never Tired

This child often does not show fatigue. Throughout the day he will always move here and there, run, jump, roll and so on.

e. Without purpose

All activities are carried out without a clear purpose. Active children, when climbing onto a chair for example, want to take food or play the role of a superman. Hyperactive children do it aimlessly, he just goes up and down.

f. Impatient and nosy

He also has no patience, when playing he has difficulty waiting his turn. He also often interferes with his friends for no apparent reason.

g. Low intelligence

Often the intellect of a hyperactive child is below the average normal child. Maybe psychologically he was mentally disturbed so he could not show his creative abilities.

The opinion above, is not entirely true. According to M.I.F Baihaqi and Sugiarmin ADHD were found at every level of intelligence. Most people have average or above average intelligence. In reality, ADHD can mask intelligence in gifted children and will show average or below average performance. ${ }^{21}$

${ }^{17}$ Ferdinand Zaviera, Anak Hiperaktif dan Gangguan Konsentrasi,(Jogjakarta: KataHati, 2008), p.11.

${ }^{18}$ Syekh Jamaludin Mahfudz, Psikologi Anak dan Remaja Muslim, (Jakarta: Pustaka al-Kautsar, 2003),p. 126.

${ }^{19}$ D.SPrasetyono,SerbaSerbiAnak.Autis(Jogjakarta:DivaPress,2008),p.107.

${ }^{20}$.Ferdinand Zaviera, Anak Hiperaktif dan Gangguan Konsentrasi(Jogjakarta: KataHati,2008),p.1 4

${ }^{21}$ M.I.F baihaqi dan Sugiarmin, Memahami Anak ADHD, (Jogjakarta: Kata Hati,2008), p.16. 
ADHD criteria based on Statistical Manual (DSM) IV1994, namely:

a. Lack of attention

At this point, $\mathrm{ADHD}$ sufferers experience at least six or more of the following symptoms, and last for at least 6 months to a level that is maladaptive and inconsistent with the level of development.

- Often fails to pay close attention to something in detail or make careless mistakes in school work and other activities.

- Often experience difficulties in focusing attention on tasks or play activities.

- Often do not listen when spoken to directly.

- Often not following instructions and failing to complete school work or workplace assignments (not due to resistance or failure to understand instructions).

- Often have difficulty in carrying out tasks and activities.

- Often the loss of items or objects important for tasks and activities, for example losing games, losing schoolwork, losing pencils, books and other stationery.

- Often avoid, dislike or be reluctant to carry out tasks that require supported mental effort, such as completing schoolwork or homework.

- Often confused / disturbed by stimuli from outside.

- Often forgets quickly in completing daily activities.

b. Impulsivity Hyperactivity

At least six or more of the following symptoms of hyperactivity impulsivity persist for at least 6 months to a level that is maladaptive and inconsistent with the level of development.

- Hyperactivity

1) Often restless with their hands or feet and often stretch out in a chair.

2) Often leaves the seat in the classroom or in other situations where it is hoped that the child will continue to sit.

3) Often running around or going up and down excessively in situations where this is not appropriate.

4) Often have difficulty in playing or engaging in leisure activities frankly.

5) Often moves or acts as if controlled by a motor.

6) Frequent excessive talking.

- Impulsivity

1) Often gives answers before the question is finished.

2) Often have difficulty waiting their turn.

Frequently interrupting or disturbing others, for example interrupting a conversation or game.

So, if it is concluded that the definition of ADHD is a condition of children who show symptoms (symptoms or symptoms) lack of concentration, hyperactivity and impulsivity which can cause an imbalance of most activities.

\section{Research Method}

In every writing of scientific work must have complete and objective data, and have certain methods and methods in accordance with the writing to be discussed. As for the type of research that researchers use in carrying out this research is descriptive qualitative research type that is a study aimed at to describe existing phenomena, they can be ongoing phenomena or past phenomena. ${ }^{22}$

22Suharsimi Arikunto, Manajemen Penelitian (Jakarta: Rineka Cipta, 2000), p. 10 
This research uses the case study method which is a study that tries to examine individuals or a unit in depth. In the case study, the research involved a single separate unit such as a family, a group or household unit. ${ }^{23}$

This study uses a qualitative approach that is research aimed at describing and analyzing phenomena, events, social activities, attitudes, beliefs, perceptions, thoughts of people individually or in groups. ${ }^{24}$ Researchers use this approach because researchers want to describe and analyze the methods of parents in providing prayer guidance to children with ADHD.

To obtain accurate data, researchers used several methods, namely:

\section{a. Observation}

Observation, which is a technique or a way to collect data by making observations about ongoing activities. ${ }^{25}$ Through this technique, researchers can see firsthand the situation and conditions in the field. Observations in this study were carried out at the home of ADHD children to directly observe the process of prayer guidance for ADHD children. The researcher found it easy to carry out this observation because the researcher was also a resident of Syamtarail Settlement in North Aceh Regency and the location of the ADHD children's parents' house was also close to the researcher's house which allowed the researcher to directly observe the guidance process of the children's prayer prayer.

\section{b. Interview}

Interview is a conversation with a specific purpose. The conversation was carried out by both parties, namely the interviewer who asked the question and the interviewee who gave the answer to the question. ${ }^{26}$ The interview technique used in this study was in-depth interviews. In this study, interviews were conducted with parents, siblings and neighbors of ADHD children to get information about the experiences and methods used when giving prayer guidance to their children who experience impaired concentration problems accompanied by hyperactivity. To facilitate the interview process, researchers try to formulate some questions that will be asked, then the questions include about:

- The experiences experienced when carrying out the prayer guidance for children with ADHD

- The methods used to teach prayer education to children with ADHD.

- Obstacles obtained when teaching ADHD child education.

- Solutions used to overcome these obstacles.

\section{Discussion}

\subsection{Factors Causing Concentration Disorders Attention accompanied by hyperactivity Children Attention Deficit Hyperactivity Didorder (ADHD)}

In a psychiatric disorder or disorder there must be a variety of factors that affect both internal and external factors. Similarly, in children who experience attention deficit disorders accompanied by hyperactivity (ADHD). The exact cause and pathology of ADHD itself has not been revealed clearly until now, because the causes of ADHD are multifactorial.

Regarding the factors causing attention deficit disorders accompanied by hyperactivity in ADHD children researchers have conducted interviews with the following results:

\footnotetext{
${ }^{23}$ Suharsimi Arikunto, Manajemen...,p. 10.

${ }^{24}$ Nana Syaodih Sukmadinata, Metode Penelitian Pendidikan (Bandung: Remaja Rosdakarya ,2007), p. 60.

${ }^{25}$ Nana Syaodih Sukmadinata, MetodePenelitian...p. 220.

${ }^{26}$ Lexy Moloeng, Metodologi Penelitian Kualitatif, (Bandung: Rosda Karya ), p.135.
} 
ADHD children are born with a normal body weight of $2.5 \mathrm{~kg}$ in the condition of not having anus. So he had to be operated on to make the artificial anus in his stomach and only to be operated on to open the original anus after reaching $10 \mathrm{~kg}$ in weight. He is among children who have difficulty eating, so reaching $10 \mathrm{~kg}$ in weight requires a long time. During that time he was a quiet child and only at home. $\mathrm{He}$ is less sociable with his friends for fear that the unpleasant smell coming from his artificial anus disturbs them. He also experienced delays walking and talking. After weighing more than $10 \mathrm{~kg}$, the team of doctors performed surgery to open the original anus. And several months later operations were performed again to close the artificial anus. This condition lasts until the age of 4 years. This is based on the statement from the child's father ADHD as follows:

When I was born my child was actually normal, weighing $2.5 \mathrm{~kg}$ but he did not have anus, so he had to be operated on to make an artificial anus in his stomach. Since childhood, eating is very small, so that its development is disrupted. When the weight has reached $10 \mathrm{~kg}$, then surgery again to open the original anus and a few months later to operate again to close the artificial anus. All of that with general anesthesia. This is due to the delay in its development, which is the delay in walking, talking and hanging out with peers. ${ }^{27}$

When he was 7 years old, he had just entered kindergarten (TK) and only lasted for 1 year, because his teacher was overwhelmed by it. For eight years he was admitted to an ordinary public elementary school which lasted only half a year, then he was educated by his parents and family at home. Only when he was 11 years old was he admitted to an Extraordinary School (SLB) until now.

Because of the late development, my child had just entered kindergarten at the age of 7 years, and there only lasted one year because his teacher was overwhelmed by it. We entered the age of 9 years at an ordinary public elementary school which only lasted half a year, then at home to educate me and his own father. Only when he was 11 years old did we enter the Special School (SLB) until now. ${ }^{28}$

a. Family history of ADHD children

Judging from the family history of ADHD children from the mother's side, no one has a disability or disorder, both physically and mentally. This is as the case with the ADHD children's neighbors as follows:

The ADHD child family is a respected family, the father of a religious leader in this village. The father of an ADHD child is a stranger, so I don't know his family history, the real person here is his mother. If from my mother's knowledge, no one has a disability or abnormality, everything is normal. ${ }^{29}$ While on the father's side, there are some members who have both physical and mental disabilities. First, the ADHD child's father's niece experienced paralysis and eventually died. Second, another father's nephew experienced speechlessness (mute) from birth. Third, still the father's niece also experienced a delay in walking and talking in her childhood. Fourth, the father's grandson had a physical disability, his fingers were deformed. This is like saying the ADHD siblings as follows:

My mother's family are all normal, with abnormalities from my father's family. First, the niece of the ADHD child's father was paralyzed until he finally died. Second, another father's nephew experienced speech impairment (mute) from birth. Third, still the father's niece also experienced a delay in walking and talking in her childhood. Fourth, grandchildren of father's brother had a physical disability, his fingers bent. ${ }^{30}$

\footnotetext{
${ }^{27}$ Interview between Father and children Attention Deficit Hyperactivity Disorder (ADHD) on Thursday, $18^{\text {th }}$ July 2019. 28 Interview between Father and children Attention Deficit Hyperactivity Disorder (ADHD) on Thursday, $18^{\text {th }}$ July 2019.

Interview of children Attention Deficit Hyperactivity Disorder (ADHD) on Thursday, 18 th July 2019.

${ }^{30}$ Interview between sister and children Attention Deficit Hyperactivity Disorder (ADHD) on Thursday, $18^{\text {th }}$ July 2019.
} 
From the results of the above interview it can be concluded that the factors that cause ADHD children experience attention deficiency disorders accompanied by hyperactivity are as follows:

- Factors of metabolic disorders

- Genetic factors

\section{b. ADHD Children Praying Mastery}

Praying is the main worship that should be taught by parents to children since childhood. For normal children aged 10-13 years, this prayer is not something that is difficult to do. Because in terms of intellectual mental development, at this age children are able to react to intellectual stimulation or carry out learning tasks that require intellectual abilities or cognitive abilities. And in terms of psychomotor development, the child is able to make movements with good coordination.

Partak ADHD of course prayer is difficult to do, because prayer requires high concentration, good motor coordination and good memorization power. Long prayer readings and various prayer movements are separate struggles for ADHD children.

As for the observations that the researchers have made regarding the ability to pray in ADHD children are as follows:

Table: Observation of the Ability to Pray for Children of ADHD

\begin{tabular}{|c|c|c|c|c|}
\hline No & Type of Competency & Yes & No & Fault \\
\hline 1 & $\begin{array}{l}\text { Able to stand when do } \\
\text { Sholat }\end{array}$ & $\sqrt{ }$ & & \\
\hline 2 & $\begin{array}{l}\text { Able to know the certain } \\
\text { Kiblat }\end{array}$ & & $\sqrt{ }$ & $\begin{array}{l}\text { ADHD child does not know } \\
\text { the direction of Qibla when he } \\
\text { will pray he is still confused } \\
\text { looking for Qibla direction }\end{array}$ \\
\hline 3 & $\begin{array}{l}\text { Able to say the words } \\
\text { and sentences in praying }\end{array}$ & & $\sqrt{ }$ & $\begin{array}{l}\text { ADHD children can not recite } \\
\text { all the intentions of prayer } \\
\text { except with guidance }\end{array}$ \\
\hline 4 & $\begin{array}{l}\text { Able to read takbiratul } \\
\text { ihram }\end{array}$ & $\sqrt{ }$ & & \\
\hline 5 & $\begin{array}{ll}\text { Raise hand when } \\
\text { takbiratul ihram }\end{array}$ & $\sqrt{ }$ & & \\
\hline 6 & $\begin{array}{l}\text { Able to read iftitah } \\
\text { prayers }\end{array}$ & $\sqrt{ }$ & & $\begin{array}{l}\text { ADHD children can read } \\
\text { prayers, sometimes they need } \\
\text { guidance }\end{array}$ \\
\hline 7 & $\begin{array}{l}\text { Able to read surah al- } \\
\text { fatihah }\end{array}$ & $\sqrt{ }$ & & \\
\hline 8 & Able to read short letters & $\sqrt{ }$ & & \\
\hline 9 & $\begin{array}{l}\text { Able to say takbir at } \\
\text { every turn of the prayer } \\
\text { movement }\end{array}$ & $\sqrt{ }$ & & \\
\hline 10 & $\begin{array}{l}\text { Able to do bowing } \\
\text { movements, }\end{array}$ & $\sqrt{ }$ & & \\
\hline 11 & $\begin{array}{l}\text { Able to read ruku prayer } \\
\text { '3 times }\end{array}$ & $\sqrt{ }$ & & \\
\hline 12 & $\begin{array}{l}\text { Being able to be calm } \\
\text { when it's not }\end{array}$ & & $\sqrt{ }$ & $\begin{array}{l}\text { ADHD children cannot be } \\
\text { calm when it's not. }\end{array}$ \\
\hline 13 & Able to read prayer isn't & $\sqrt{ }$ & & \\
\hline
\end{tabular}




\begin{tabular}{|c|c|c|c|c|}
\hline 14 & $\begin{array}{l}\text { Able to make } \\
\text { prostrations }\end{array}$ & $\sqrt{ }$ & & \\
\hline 15 & $\begin{array}{l}\text { Able to read prostrations } \\
\text { for } 3 \text { times }\end{array}$ & $\sqrt{ }$ & & \\
\hline 16 & $\begin{array}{l}\text { Able to sit between two } \\
\text { prostrations }\end{array}$ & $\sqrt{ }$ & & \\
\hline 17 & $\begin{array}{l}\text { Able to recite prayers } \\
\text { sitting between two } \\
\text { prostrations }\end{array}$ & & $\sqrt{ }$ & $\begin{array}{l}\text { ADHD children have not } \\
\text { memorized the prayer sitting } \\
\text { between the two prostrations }\end{array}$ \\
\hline 18 & Able to do sit iftirasy & & $\sqrt{ }$ & $\begin{array}{l}\text { ADHD children can not sit } \\
\text { down iftirasy still confused to } \\
\text { sit with tawaru, }\end{array}$ \\
\hline 19 & $\begin{array}{l}\text { Able to read the early } \\
\text { tasyahud prayers }\end{array}$ & & $\sqrt{ }$ & $\begin{array}{l}\text { The ADHD child is only able } \\
\text { to read some parts of the early } \\
\text { teachings, he still needs } \\
\text { guidance }\end{array}$ \\
\hline 20 & Able to do bargaining & & $\sqrt{ }$ & $\begin{array}{l}\text { ADHD child can not sit } \\
\text { bargaining, he is still confused } \\
\text { to distinguish from sitting } \\
\text { iftirasy }\end{array}$ \\
\hline 21 & $\begin{array}{l}\text { Able to read the final } \\
\text { tasyahud }\end{array}$ & & $\sqrt{ }$ & $\begin{array}{l}\text { The ADHD child only reads a } \\
\text { few parts of the final tasyahud, } \\
\text { he still needs guidance }\end{array}$ \\
\hline 22 & $\begin{array}{l}\text { Being able to distinguish } \\
\text { the number of rak'ats at } \\
\text { each of the } 5 \text { daily } \\
\text { prayers }\end{array}$ & & $\sqrt{ }$ & $\begin{array}{l}\text { ADHD children have not } \\
\text { been able to distinguish the } \\
\text { number of rak'ats at each } \\
\text { prayer }\end{array}$ \\
\hline 23 & Able to recite salam & $\sqrt{ }$ & & \\
\hline 24 & $\begin{array}{l}\text { Able to do salam } \\
\text { movement }\end{array}$ & & $\sqrt{ }$ & $\begin{array}{l}\text { ADHD children have not } \\
\text { been able to make the correct } \\
\text { salam movements }\end{array}$ \\
\hline 25 & $\begin{array}{l}\text { Able to distinguish } \\
\text { movement and reading } \\
\text { between rakaat }\end{array}$ & & $\sqrt{ }$ & $\begin{array}{l}\text { ADHD children have not } \\
\text { distinguished praying and } \\
\text { movement in sholat }\end{array}$ \\
\hline 26 & $\begin{array}{l}\text { Able to do } \begin{array}{l}\text { shalat as } \\
\text { appropriate } \\
\text { sholat }\end{array} \\
\text { asrukun }\end{array}$ & & $\sqrt{ }$ & $\begin{array}{l}\text { ADHD children have not } \\
\text { been able to distinguish } \\
\text { reading and movement in } \\
\text { prayer }\end{array}$ \\
\hline
\end{tabular}

In general, ADHD children have not performed prayers with discipline, the most common prayers are Maghrib and Isha Prayers. ADHD children do not know the aurat of prayer and the things that cancel prayer. ${ }^{31}$

\subsection{Family Method in Guidance for Prayers in Children Attention Deficit Hyperactivity Didorder (ADHD)}

Effective guidance for ADHD children is home-centered guidance. Because children's time is spent more at home than at school. Guidance that involves all family members will be optimal because

\footnotetext{
${ }^{31}$ Interview between Father and children Attention Deficit Hyperactivity Disorder (ADHD) on Thursday, $18^{\text {th }}$ July 2019.
} 
they know the character of the child better. Guidance on praying done by parents towards ADHD children aims to prepare for their baligh period. The hope is that when entering baligh later ADHD children can already perform their prayers independently. In this case the size of baligh is different from normal children his age. Because after all ADHD child parents cannot continue to guide him. ${ }^{32}$

Guidance on prayer and ablution skills has been carried out by parents since ADHD children were 5 years old and still continues today. However, this guidance is more focused on the prayer rather than ablution. Regarding ablution parents cannot continuously supervise and accompany children with ADHD to the bathroom to perform Wudhu. ${ }^{33}$

This guidance involves all family members, namely fathers, mothers, siblings and cousins of ADHD children. All members guide the prayer properly and correctly. At first the ADHD's child's father was the most dominant in this guidance, while the mother was just a reminder. When he was 10 years old, this guidance also involved a cousin who lived in the same house with him. And when he was 12 years old, this guidance was dominated by his older siblings because of the increasing activity of parents. ${ }^{34}$ When the ADHD child was a child, the parent's method of guidance was to try to teach the readings of the prayer directly, but this was less successful because he rarely wanted and always wanted to run away when taught, after which they were never taught again. ${ }^{35}$ ADHD children also learn about prayer readings and their movements from the TPQ (al-Qur'an Education Park) children in mosques. By watching, observing, listening to and imitating TPQ children who practice prayer finally they can gradually recite their prayers and their movements. So at home only deepens the knowledge gained at TPQ. ${ }^{36}$

Guidance by the family of children with ADHD is to read aloud that they want to be taught repeatedly and naturally they will follow. That shows that the desire to learn began to emerge. After that, the parents just need to fix the wrong thing. ${ }^{37}$ When learning an ADHD child is very easily bored and tends to be easily agitated to quickly die in a place of learning, learning an ADHD child is also very dependent on mood, one way to arouse his mood by giving a reward. This reward is not always in the form of goods or prizes, but in the form of doing something that is liked. With this ADHD children are usually going to the spirit of prayer and according to being guided. In addition to mood, parents also need to know the most appropriate time to teach him, that is after the Maghrib Prayer and before going to sleep because at this time he is not playing anymore. ${ }^{38}$ So it can be concluded that the method used by the family in the guidance of prayer in ADHD children is as follows:

\section{a. By setting an example}

This example comes from two environments, namely the family environment and the environment around ADHD children. ADHD child family is a religious family, they pray 5 times with discipline even often pray in congregation either in the mosque or at home. This situation is good for children with ADHD. From here, he sometimes watched and imitated. Exemplary in the form of giving examples by reading aloud the reading you want to teach is also very helpful for ADHD children. In addition, ADHD children also learn from TPQ (Al-Qur'an Education Park), by imitating TPQ children practicing prayer.

\footnotetext{
32Interview between Father and children Attention Deficit Hyperactivity Disorder (ADHD) on Thursday, $18^{\text {th }}$ July 2019.

${ }^{33}$ Interview between Father and children Attention Deficit Hyperactivity Disorder (ADHD) on Thursday, $18^{\text {th }}$ July 2019.

${ }^{34}$ Interview between sister and children Attention Deficit Hyperactivity Disorder (ADHD) on Thursday, $18^{\text {th }}$ July 2019.

${ }^{35}$ Interview between Father and children Attention Deficit Hyperactivity Disorder (ADHD) on Thursday, $18^{\text {th }}$ July 2019.

${ }^{36}$ Interview between Father and children Attention Deficit Hyperactivity Disorder (ADHD) on Thursday, $18^{\text {th }}$ July 2019.

${ }^{37}$ Interview between sister and children Attention Deficit Hyperactivity Disorder (ADHD) on Thursday, $18^{\text {th }}$ July 2019.

${ }^{38}$ Interview between Father and children Attention Deficit Hyperactivity Disorder (ADHD) on Thursday, $18^{\text {th }}$ July 2019.
} 


\section{b. Habituation}

Families continue to get used to pray in ADHD children when entering prayer time by always inviting and reminding ADHD children to pray. In this habituation method, rewarding is also done if an ADHD child craves and does not want to pray.

\section{c. Monitoring}

Families of ADHD children always accompany ADHD children when praying by reading aloud recitation of prayer. This assistance is also to justify mistakes in reading or prayer movement. So that the ADHD child knows his mistake and does not repeat it again in the future. The difficulty in teaching ADHD children the most felt by their families is their low concentration power. So he tends to get bored easily. When taught he was restless to immediately leave the place. ${ }^{39}$

\subsection{Analysis of Data About Family Methods in Guiding Children's Prayers Attention Deficit Hyperactivity Didorder (ADHD)}

The family of ADHD children has taught the skills of worship to ADHD children since the age of 5 years. This teaching aims to prepare ADHD children to enter the burden of obligation during their baligh years. So that when baligh later he was able to carry out prayer independently. This teaching involves all family members who live in the same house with ADHD children, including the father, mother, siblings and cousins of ADHD children. Teaching prayer skills in ADHD children is more to deepen the knowledge that has been acquired by ADHD children in the Al-Qur'an Education Park (TPQ). ADHD children learn from paying attention to and participating in the students of the Islamic QQQ who practice prayer in the afternoon.

The family method in teaching ADHD children's prayer skills is as follows: a. Diligence

First, exemplary without teaching directly, namely parents and other family members perform prayers in an orderly manner and often congregate in front of ADHD children. Second, the example by teaching directly is to read aloud the reading that wants to be taught repeatedly near an ADHD child, so that because an ADHD child is familiar with the reading, he finally imitates.

Education with this example is an effective education for children with ADHD given the character of

ADHD children who cannot be silent when taught and very dependent on mood. With this example, ADHD children indirectly or accidentally learn on their own, because basically children learn by imitating. This is as said by Mansur that religious acts carried out by children at the base are obtained from imitating. Praying and praying for example, they carry out because they see the reality of the environment, both in the form of habituation or intensive teaching. In all cases children are accomplished imitators and the nature of these imitators is positive capital in children's religious education. ${ }^{40}$

\section{b. With habituation}

The next method performed by families of the ADHD children's prayer skills is through habituation. When prayer time arrives, ADHD children are always reminded and invited to pray. This habituation method also involves children in the Qur'an Education Park (TPQ). DiTPQ ADHD children will be motivated to pray with enthusiasm because he likes the activities carried out together. In this habituation method giving rewards (gifts) is often done when an ADHD child is sulking and does not want to perform the prayer. Giving rewards (prizes) makes ADHD children eager to pray. The above is in accordance with the wisdom of the approach to reward and gift giving that is a pleasant

${ }^{39}$ Wawancara dengan Kakak anak Attention Deficit Hyperactivity Disorder (ADHD) on Thursday, 18 July 2019.

${ }^{40}$ Mansur, Pendidikan Anak Usia Dini dalam Islam (Yogyakarta: Pustaka Pelajar, 2005), p. 55. 
emotional condition that is built up within the child, so that the child feels happy, satisfied and happy and will further strengthen the impulses that work to activate the behavior in the child. ${ }^{41}$

\section{c. With Monitoring}

The next step is monitoring. The point is to correct errors in reading and prayer movements. And to ensure that ADHD children complete each prayer according to the number of rak'ahs. This method is very good because ADHD children do not have the awareness to perform their own prayers. And considering the mastery of ADHD child prayer is still not perfect. Without these efforts, it is feared that the mistakes of ADHD children will be brought to adulthood. The method used by the family above still does not meet the stages of teaching children the correct prayer. According to Musthofa Abul Mu'athi, the stages of teaching children's prayers are, 1) the practical stage, focusing on direct observation and training. 3) the application and monitoring stage, observing the children praying to justify their mistakes. ${ }^{42}$

So it can be said the lack of guidance and teaching in ADHD children is at the theoretical stage, so that the types of prayer competencies that have not been mastered by ADHD children revolve around things that are theoretical and understanding. This is understandable because teaching things that are theoretical in ADHD children need to struggle hard from the family given the character of ADHD children who have difficulty concentrating and low cognitive abilities. Therefore we need appropriate methods and media that are adapted to the character of ADHD children accompanied by extraordinary patience from the family.

\section{Conclusion}

Based on the results of research and analysis of the authors about the methods of parents in fostering the prayer of ADHD children prayer (case study of children with ADHD in Syamtarail North Aceh Settlement) can be concluded as follows:

a. The method used by parents of ADHD children in providing coaching or education about the worship of their children who experience concentration and hyperactivity disorders or what is often referred to as ADHD is through exemplary methods, habituation, refraction and monitoring.

b. Obstacles experienced by parents of ADHD children when giving guidance or education on prayer for their children who experience concentration and hyperactivity disorders or ADHD is very low power of concentration, tends to get bored easily, when taught, he is restless to immediately leave the place.

c. When experiencing obstacles such as those mentioned above ADHD child parents take an alternative by teaching their children who have ADHD when their hearts or mood are good, to arouse the learning mood of ADHD children they promise to give rewards (gifts) and invite them to listen to music that they like.

Lack of guidance and teaching in ADHD children, namely in matters that are theoretical. This can be understood because of the difficulty of direct guidance and teaching of ADHD children.

\section{References}

\footnotetext{
${ }^{41}$ Musthofa Abul Mu'athi, Mengajari Anak Shalat Teori dan Praktek, translated. Kamran As'ad Irsyady (Bandung:ibs,2007), p.212.

42Musthofa Abul Mu'athi, Mengajari Anak...,p. 97.
} 
Al-Nahlawy, Abdurrahman. (1995). Pendidikan Islam di Rumab, Sekolab dan Masyarakat, translation. Shihabuddin. Jakarta: GemaInsani Press.

Arifin. (19910). M Ilmu Pendidikan Islam, (Suatu Tinjauan Teoritis dan Praktis Berdasarkan Pendekatan Interdisipliner).Jakarta:Bumi Aksara,

Arikunto, Suharsimi. (2003.). Prosedur Penelitian Suatu Pendekatan Praktek, Edisi Revisi V. Jakarta: Rineka Cipta

(2000).Manajemen Penelitian. Jakarta: Rineka Cipta.

Depag RI. (2005). Mushafal-Qur'an Translation. Jakarta: Al- Huda Kelompok Gema Insani.

Djamarah,Syaiful Bahri.(2004). Pola Komunikasi Orang Tua dan Anak dalam Keluarga: Sebuah Perspektif Pendidikan Islam. Jakarta: Rineka Cipta.

Hery, dkk. (2000).W atak pendidikan islam, Jakarta: Friska Agung Insani.

Imam Muslim, Shaleh Muslim.(1937) Juz. I, isa Al-Halaby wa auladuhu, Mesir.

Mahfudz, Syekh Jamaludin. (2003). Psikologi Anakdan Remaja Muslim.Jakarta: Pustakaal-Kautsar.

Moloeng, Lexy J. (2002).Metodologi Penelitian Kualitatif. Bandung: Remaja Rosdakarya.

Prasetyono, D.s.( 2008). Serba-Serbi Anak Autis. Jogjakarta: Diva Press.

Qardhawi,Yusuf. (2008)Fiqih Puasa. Solo: Era Intermedia.

Rohmah, Elfi Yuliana. (2005). Psikologi Perkembangan. Ponorogo: STAIN Ponorogo Press,

Sugiono. (2006). Metode Penelitian Pendidikan. Pendekatan Kuantitatif, Kualitatif dan R\&D. Bandung: Alfabeta.

Sukmadinata, Nana Syaodih. (2007). Metode Penelitian Pendidikan. Bandung: Remaja Rosdakarya,

Zakiah Darajat. (1978).Ilmu Jiwa Agama, Jakarta: Bulan Bintang.

Zaviera,Ferdinand.(2008). Anak. Hiperaktif dan Gangguan Konsentrasi. Jogjakarta: KataHati. 